\title{
Molecular Study of the G1 Haplotypes of Echinococcus granulosus from Iran Based on Cytochrome C Oxidase (Subunit 1) Sequence
}

\author{
İran Kökenli Echinococcus granulosus G1 Haplotiplerinin Sitokrom C Oksidaz (Alt Ünite 1) \\ Dizilimine Dayalı Moleküler Çalışması
}

\author{
Majid Esmaelizad, H Zeinedin, Naser Razmaraii, Ali Mirjalili \\ Department of Central Laboratory, Razi Vaccine and Serum Research Institute, Karaj, Iran
}

\begin{abstract}
Objective: In this study, we attempted to identify new Echinococcus granulosus isolates in the North West provinces of Iran based on the mitochondrial cytochrome c oxidase subunit 1 (CO1) sequence.

Methods: Twenty-nine hydatid cysts from sheep and goats were collected. Genomic DNAs were extracted, and a partial sequence of the CO1 gene was amplified. Polymerase chain reaction products were cloned and sequenced with M13 primers in both directions.

Results: All Iranian isolates were located in G1 and G3 genotypes. For the first time, a new G1 haplotype in two Iranian isolates were identified.

Conclusion: It seems that this new haplotype was transmitted from Jordan to Iran or vice versa. (Turkiye Parazitol Derg 2015; 39: 286-90)

Keywords: Echinococcus granulosus, Cytochrome c oxidase, Genotyping

Received: 10.05 .2015

Accepted: 09.11.2015
\end{abstract}

ÖZ

Amaç: Bu çalışmada İran'ın kuzey batı bölgelerinde bulunan yeni bir Echinococcus granulosus izolatını mitokondriyal sitokrom c oksidazı alt ünitesi 1 (CO1) dizilimine dayanarak tanımlamaya çalıştık.

Yöntemler: Koyun ve keçilerden 29 hidatik kist alındı. Genomik DNA'lar çıkarıldı ve kısmi CO1 dizilimi amplifiye edildi. PCR ürünleri klonlandı ve her iki yönde M13 primerleri ile dizildiler.

Bulgular: Tüm İran izolatları G1 ve G3 genotiplerinde yerleşimliydi. İki İran izolatında yeni bir G1 haplotip ilk defa tanımlandı.

Sonuç: Bu yeni haplotipin Ürdün'den İran'a ya da tam tersi yönde aktarıldığı düşünülmektedir. (Turkiye Parazitol Derg 2015; 39: 286-90)

Anahtar Kelimeler: Echinococcus granulosus, Sitokrom c oksidaz, Genotipleme

Geliş Tarihi: 10.05.2015 Kabul Tarihi: 09.11.2015

\section{INTRODUCTION}

Cystic echinococcosis (CE) is caused by infection with the larval stage of the Echinococcus granulosus (E. granulosus) hydatid. Ten heterogeneous groups were identified in E. granulosus, defined as strains G1-G10, based on mitochondrial DNA $(1,2,3)$. However, these strains are now simplified within distinct species $(4,5)$. E. granulosus includes strains $G 1, G 2$, and $G 3$; $E$. equinus contains strain G4; and E. ortleppi contains strain G5. Strains G6-G10 have been also classified under a well-supported mono- phyletic species, E. canadensis $(3,4,6)$. Recently, the lion strain has been characterized as another new species, $E$. felidis (7). Cystic echinococcosis is endemic in Iran, particularly in the North West provinces that are close to Iraq, Turkey, and Azerbaijan (8). Three genotypes (G1, G2, and G3) have been reported previously from Iran; $\mathrm{G} 1$ was the predominant genotype $(8,11)$.

In this study, we attempted the molecular characterization and genotyping of new Iranian isolates of $E$. granulosus based on the CO1 partial sequence.

Address for Correspondence / Yazışma Adresi: Dr. Majid Esmaelizad. E.mail: m.esmaelizad@rvsri.ac.ir DOI: 10.5152/tpd.2015.4292

(C) Copyright 2015 Turkish Society for Parasitology - Available online at www.tparazitolderg.org

CTelif hakkı 2015 Türkiye Parazitoloji Derneği - Makale metnine www.tparazitolderg.org web sayfasından ulaşılabilir. 
Table 1. CO1 nucleotide sequences from different genotypes

\begin{tabular}{|c|c|c|c|}
\hline Accession no. & Origin & Accession no. & Origin \\
\hline HM598459.1 & G1-Turkey-buffalo-2011 & JX854028.1 & G3-India-2013 \\
\hline HM598454.1 & G1-Turkey-buffalo-2011 & EU006777.1 & G1-Turkey-sheep-2008 \\
\hline EU929083.1 & G1-Turkey-sheep-2008 & EF693892.1 & Turkey-2008 \\
\hline EU178103.1 & G1-Turkey-cattle-2008 & DQ856467.1 & G1-Italy-sheep \\
\hline HF947572.1 & G1-G3 ovis Portugal2013 & JQ250807.1 & G1-Iran-2012 \\
\hline HF947571.1 & G1-G3 ovis Brazil-2013 & GQ856692.1 & G1- Iran-2009 \\
\hline HF947570.1 & G1-G3 ovis Italy-2013 & DO356882.1 & G1-China-2006 \\
\hline GU951512.1 & G1-Turkey-H. sap.-2011 & EF367286.1 & G1-Morocco-2007 \\
\hline KC109659.1 & G1 palestine-sheep-2013 & HF947597.1 & G1-Portugal-2013 \\
\hline EU178105.1 & G1-Turkey-Cattle-2008 & AB688621.1 & G1-Peru-2012 \\
\hline EF545563.1 & G1-Turkey-sheep-2008 & JX854029.1 & G1-India-2012 \\
\hline DQ269946.1 & India 2007 & KC109651.1 & G1-Palestine-2013 \\
\hline AB688596.1 & G1-Jordan-2012 & JQ250816.1 & G1-Iran-2012 \\
\hline AB688141.1 & G1-Russia-2011 & AB688592.1 & G1-Jordan-2012 \\
\hline GQ502231.1 & G1-G3 Chile-2009 & JX854028.1 & G3-India-2013 \\
\hline EU929083.1 & G1-Turkey -2008 & JX068639.1 & G4-UK-2012 \\
\hline JN604103.1 & G2-Iran-2012 & AB235846.1 & G5-Japan-2009 \\
\hline AB688142.1 & G6-Japan-2013 & DQ144021.1 & G8-Australia-2008 \\
\hline JQ356719.1 & G7-France-2012 & KC415063.1 & G9-India-2013 \\
\hline DQ144017.1 & G10-Australia-2006 & & \\
\hline
\end{tabular}

\section{METHODS}

\section{Isolates}

Twenty-nine hydatid cysts from the infected liver of the intermediate host (20 sheep and 9 goats) from local abattoirs in two main provinces of the North West region of Iran (West and East Azerbaijan) where CE is endemic were collected.

\section{DNA extraction and polymerase chain reaction (PCR)}

Genomic DNA was extracted from the germinal layer of the cyst using the phenol/ chloroform/isoamyl alcohol method as described previously (10). A portion of the CO1 mitochondrial gene, which codes for the subunit 1 of cytochrome c oxidase, was amplified by PCR.

Two primers were designed using the Oligo software: Forward 5'-TाT TTG GGC ATC CTG AGG TाT AT-3' and Reverse 5'-TAA AGA AAG AAC ATA ATG AAA ATG-3'. PCR was performed in a 50 $\mu \mathrm{l}$ reaction mixture containing $5 \mu \mathrm{l}$ of $10 \mathrm{X}$ reaction buffer, $1.5 \mathrm{mM}$ $\mathrm{MgCl}_{2}, 2.5 \mathrm{mM}$ each of dNTPs, 0.5 unit Taq DNA polymerase enzyme (Fermentase), 10 pmol of each primer, and $100 \mathrm{ng}$ of DNA. The PCR program used to amplify the CO1 gene included an initial denaturation step of $95^{\circ} \mathrm{C}$ for $3 \mathrm{~min}, 35$ cycles of $95^{\circ} \mathrm{C}$ for $1 \mathrm{~min}, 52^{\circ} \mathrm{C}$ for $30 \mathrm{~s}, 72^{\circ} \mathrm{C}$ for $1 \mathrm{~min}$, and final extension at $72^{\circ} \mathrm{C}$ for $5 \mathrm{~min}$. The PCR products were visualized and evaluated in a $1 \%$ agarose gel.

\section{Cloning and sequencing of PCR products}

The PCR product of the CO1 gene was electrophoresed using $1 \%$ agarose gel, and the specific band was purified from the gel.
The ligation reaction consists of the T-vector $(0.165 \mu \mathrm{g})$, purified PCR product (0.54 pmol ends), 10X ligation buffer $(3 \mu \mathrm{l})$, PEG $4000(3 \mu \mathrm{l}), 1 \mu \mathrm{l}$ T4 DNA ligase, and deionized water up to $30 \mu \mathrm{l}$. The ligation mix is incubated at $22^{\circ} \mathrm{C}$ for $16 \mathrm{~h}$. The ligation product was transformed into Escherichia coli strain XL1 blue, and the positive colony was selected using PCR (Sambrook et al., 1989). Positive plasmids were purified and then sequenced by M13 primers. The resulting sequences were analyzed by BLAST and MegAlign software.

\section{Genotype identification}

The multiple alignment and phylogenic tree were designed by MegAlign 5.0 software. Iranian isolates were compared to other sequences of CO1 from $10 \mathrm{E}$. granulosus genotypes (Tables 1). The nucleotide sequences were clustered by the Clustal W method.

\section{RESULTS}

\section{PCR amplification and sequencing}

A partial sequence of the CO1 gene (445 bp) was amplified in all 29 samples. The PCR products were sequenced in both directions by the Sanger method (Figure 1).

\section{Genotyping}

Iranian isolates were genotyped based on the nucleotide sequence alignment (nucleotide positions 93, 103, 142, 148, 232, 265, 268, and 294) of the CO1 gene (Figure 3). Iranian isolates showed homology with two distinct G1 and G3 genotype groups (Figure 2). 


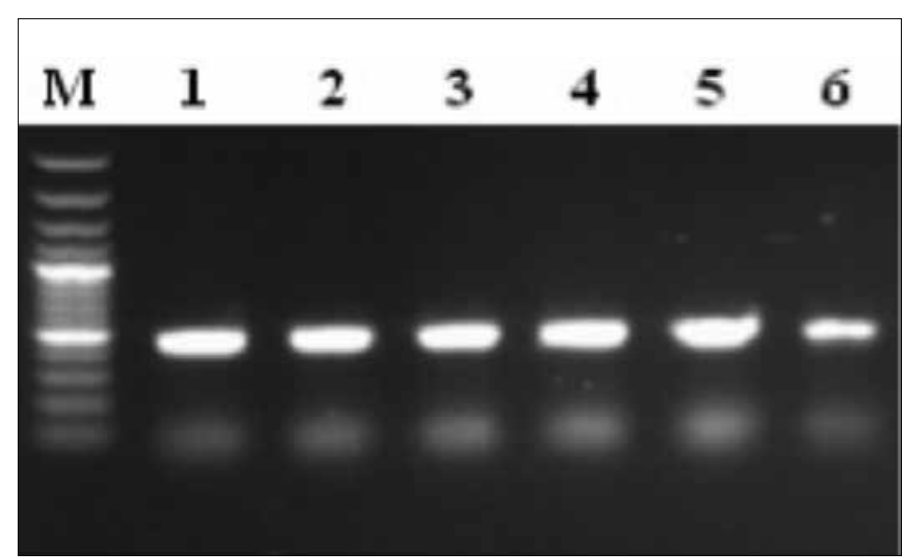

Figure 1. Electrophoresis of the PCR products using 2\% agarose gel. M: 100 bp DNA marker and 1-6: PCR products of the CO1 partial sequence

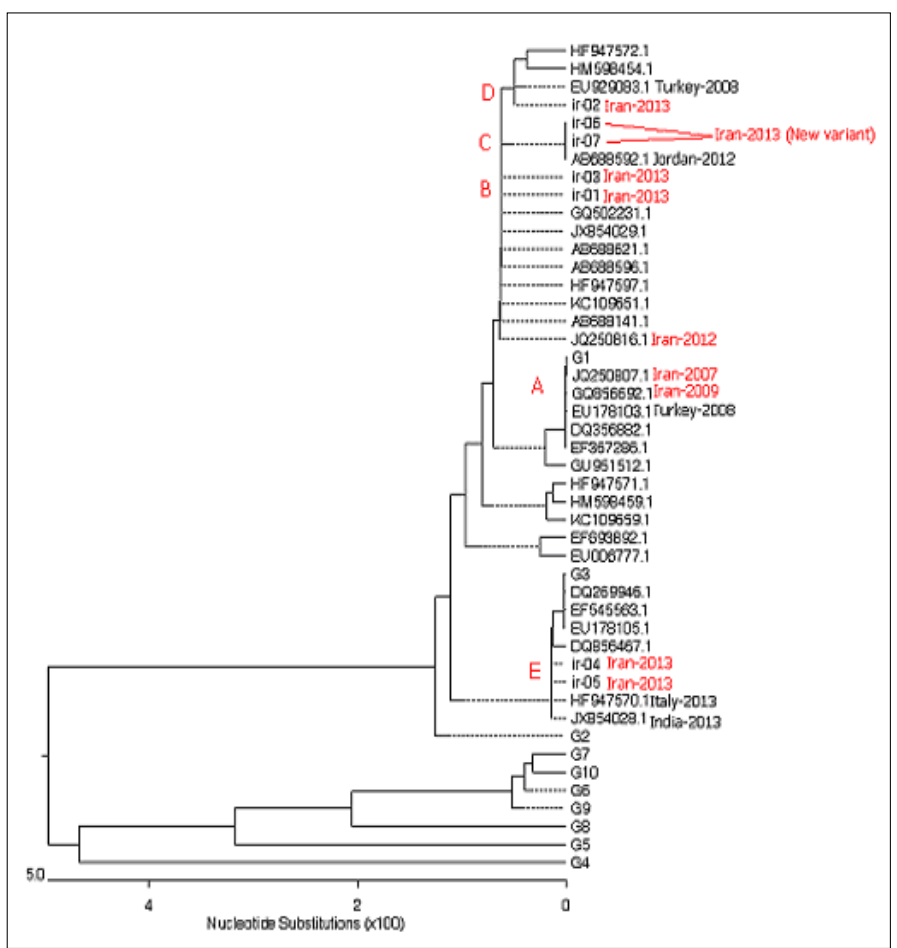

Figure 2. Dendrogram constructed with the $\mathrm{CO} 1$ mitochondrial gene sequences obtained from the different samples evaluated in this study. The sequences were compared with the sequences of E. granulosus genotypes G1-G10. Phylogeny tree analysis was performed using the MegAlign software.

\section{Polymorphism in $\mathrm{CO} 1$}

The CO1 sequences of Iranian isolates were compared with the available sequences of different genotypes (G1-G10) in GenBank. Multiple alignments displayed 49 single nucleotide polymorphisms (SNPs) (Figure 3). The G1 genotype showed a unique pattern (nucleotide " $T$ ") in position 148, but in all Iranian isolates, this position occupied by " $\mathrm{C}$ " was identical to the G2-G3 pattern (Figure 3). Interestingly, two Iranian G1 isolates (Ir-06 and Ir-07) showed the same pattern (nucleotide C) with the G8 genotype at the nucleotide position 268 (Figure 3). This is the new haplotype of the G1 genotype that was identified in Iran for the first time.
Forty-six sequences were used for phylogeny tree analysis, including new Iranian isolates and 10 genotypes reference sequences. This analysis showed that seven Iranian samples were grouped into two specific G1 (23 samples, 79.31\%) and G3 (six samples, 20.69\%) genotype groups (Figure 2). Our data demonstrates that the G1 group genotype was formed by two single nucleotide patterns that were separated. The most important was an assemblage of one single nucleotide pattern (nucleotide C) found in two samples (ir-06 and ir-07) similar to the G8 genotype in nucleotide position 268 (Figure 3), and the other observed G1 genotype group showed the reference profile. In the second group, 2 of the 7 Iranian samples (Ir-04 and Ir-05) were located in the G3 genotype group (Figure 2).

Forty-six CO1 sequences included different Iranian isolates from 2007 to 2013, and the sequences of 10 genotypes of E. granulosus were used to design a phylogeny tree (Figure 2). All Iranian isolates were located in five groups in two genotypes $\mathrm{G} 1$ and G3. Iranian G1 genotypes were located in different groups. All G1 isolates in 2013 showed divergence with other isolates of Iran in 2007-2009 and showed maximum similarity with isolates from Turkey (group D). Two isolates of Iran (Ir-06 and Ir-07) and an isolate from Jordan were located in the new unique G1 subgroup (group C) (Figure 2). These are new variants of the G1 genotype with a unique nucleotide in position 268 , similar to the G8 cervid strain (Figure 3).

\section{DISCUSSION}

E. granulosus comprises a complex of genotypes, and its molecular genetic studies identified 10 genotypes (G1-G10) included in this taxon. The molecular study of the mitochondrial DNA (mtDNA) of E. granulosus classified this complex into E. granulosus sensu stricto (genotypes G1, G2, and G3), E. equinus (G4), E. ortleppi (G5), and another taxon E. canadensis (G6-G10). The main purpose of this study was to perform a genotype analysis and evaluate the polymorphisms of the $\mathrm{CO} 1$ gene for the identification of new variants within the Iranian isolates of $E$. granulosus. Based on one mitochondrial gene (CO1), we assessed the polymorphisms of 29 samples collected from different North West provinces of Iran. The mitochondrial markers could be discriminated into two separate groups, corresponding to samples from E. granulosus sensu stricto. In this study, genotype G3 and the new haplotype of genotype G1 was found in sheep in the North West province of Iran. In nucleotide position 148, nucleotide " $\mathrm{C}$ " was observed in all Iranian G1 isolates; however, nucleotide " $T$ " was observed in the G1 reference sequence (EU178103.1, isolate from Turkey, 2008).

On the other hand, in SNPs in position 268, two Iranian G1 isolates, Ir-06 and Ir-07, showed similar nucleotide " $\mathrm{C}$ " with the G8 cervid strain. This position is a new variation in $\mathrm{G} 1$ genotypes. Interestingly, both changes in nucleotide positions 148 and 268 were observed simultaneously in both isolates Ir-06 and Ir-07.

This new variant has not been previously reported in Iran $(9,11)$. There are hundreds of $\mathrm{CO} 1$ sequences of $E$. granulosus in GenBank, but this new pattern in Iranian G1 genotype is absolutely unique.

Based on the nucleotide sequence database of NCBI, there is only one case of a sequence with maximum identity with the two 


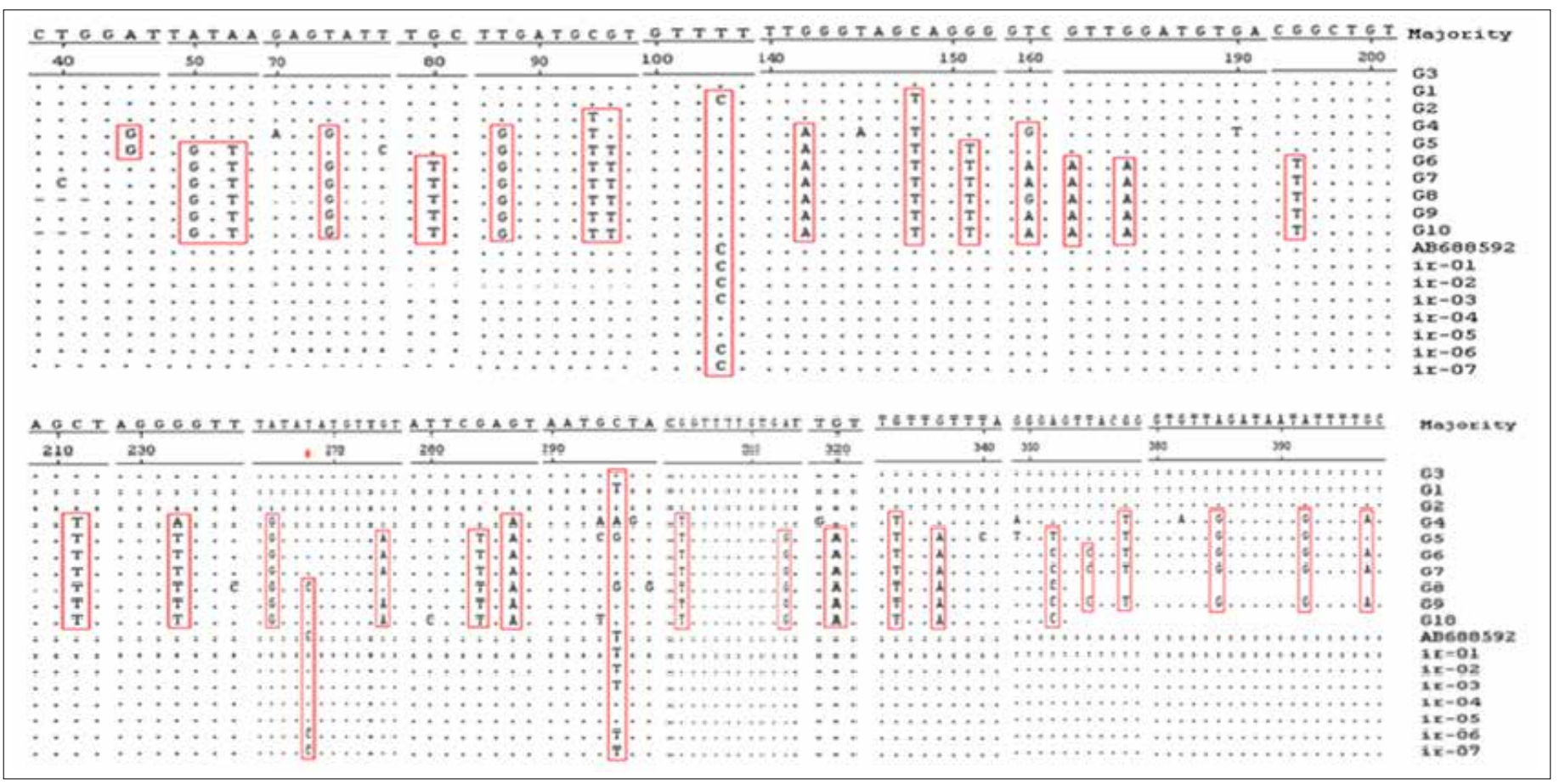

Figure 3. Multiple alignment of the CO1 nucleotide sequences of Iranian isolates and different genotypes.

isolates Ir-06 and Ir-07. It was a deposited sequence from Jordan (AB688592). It seems that this genotype was transmitted from Jordan to Iran or vice versa. Although hydatidosis is endemic in north Iraq (12) and other regional countries, no report of this new haplotype from other neighboring countries has been found. Our study strongly suggests that this new G1 genotype is seen in other neighboring countries such as Turkey, Iraq, Syria, and Azerbaijan.

\section{CONCLUSION}

This new pattern provides evidence of the new transmission of E. granulosus from abroad because of domestic or wild animal trafficking across the western border of our country. We believe that we need to take more care of the boundary condition for the control of the disease.

Ethics Committee Approval: Ethics Committee Approval was not received due to the retrospective nature of the study.

Informed Consent: Informed consent was not received due to the retrospective nature of the study.

Peer-review: Externally peer-reviewed.

Author Contributions: Consept - M.E.; Design - M.E.; Supervision M.E.; Data Collection and/or Processing - H.Z., N.R.; Analysis and/or Interpretation - M.E.; Literature Review - M.E.; Writer - M.E.; Critical Review - A.M.

Conflict of Interest: No conflict of interest was declared by the authors.

Acknowledments: We would like to thank our colleagues; Mrs. Hashemnejad and Mr. Hejazi for assistance in this research.

Financial Disclosure: This was supported by the Razi Vaccine and Serum Research Institute (Project No.1-18-189101).
Etik Komite Onayı: Çalışmamızın retrospektif tasarımından dolayı etik kurul onayı alınmamıştır.

Hasta onamı: Çalışmamızın retrospektif tasarımından dolayı hasta onamı alınmamıştır.

\section{Hakem Değerlendirmesi: Dış Bağımsız.}

Yazar Katkıları: Fikir- M.E.; Tasarım - M.E.; Denetleme - M.E.; Veri Toplanması ve/veya işlemesi - H.Z., N.R.; Analiz ve/veya Yorum - M.E.; Literatür taraması - M.E.; Yazıyı Yazan -M.E.; Eleştirel İnceleme - A.M.

Çıkar Çatışması: Yazarlar çıkar çatışması bildirmemişlerdir.

Teşekkür: Yazarlar, Bayan Hashemnejad ve Bay Hejaziye desteklerinden dolayı teşekkür ederler.

Finansal Destek: Bu çalışma Razi Aşı ve Serum Araştırma Enstitüsü tarafından 1-18-189101 kodlu proje ile desteklenmiştir.

\section{REFERENCES}

1. Bowles J, Blair D, McManus DP. Genetic variants within the genus Echinococcus identified by mitochondrial DNA sequencing. Mol Biochem Parasitol 1992; 54: 165-73. [CrossRef]

2. Bowels JD, McManus DP. NADH dehydrogenase 1 gene sequences compared for species and strains of the genus Echinococcus. Int $J$ Parasitol 1993; 23: 969-72. [CrossRef]

3. Lavikainen A, Lehtinen MJ, Meri T, Hirvela-koski V, Meri S. Molecular genetic characterization of the Fennoscandian cervid strain, a new genotypic group (G10) of Echinococcus granulosus. Parasitol 2003; 127: 207-15. [CrossRef]

4. Romig T, Dinkel A, Mackenstedt U. The present situation of echinococcosis in Europe. Parasitol Int 2006; 55: 187-91. [CrossRef]

5. Thompson RC, McManus DP. Towards a taxonomic revision of the genus Echinococcus. Trends Parasitol 2002; 18: 452-7. [CrossRef]

6. Nakao M, McManus DP, Schantz PM, Criag PS, Ito, A. A molecular phylogeny of the genus Echinococcus inferred from complete mitochondrial genomes. Parasitology 2007; 134: 713-22. [CrossRef] 
7. Hüttner M, Nakao, M, Wassermann T, Siefert L, Boomker JD, Dinkel $A$, et al. Genetic characterization and phylogenetic position of Echinococcus felidis (Cestoda Taeniidae) from the African lion. Int J Parasitol 2008; 38: 861-8. [CrossRef]

8. Pezeshki A, Akhlaghi L, Sharbatkhori M, Razmjou E, Oormazdi H, Mohebali M, Meamar AR. Genotyping of Echinococcus granulosus from domestic animals and humans from Ardabil Province, northwest Iran. J Helminthol 2012; 10: 1-5.

9. Parsa F, Fasihi Harandi M, Rostami S, Sharbatkhori M. Genotyping Echinococcus granulosus from dogs from Western Iran. Exp Parasitol 2012; 132: 308-12. [CrossRef]
10. Sambrook J, Fritsch EF and Maniatis T. Molecular cloning: A laboratory Manual, 1989; Cold Spring Harbor Press, Cold Spring Harbor, NY.

11. Pour AA, Hosseini SH, Shayan P. Comparative genotyping of Echinococcus granulosus infecting buffalo in Iran using cox1 gene. Parasitol Res 2011; 108: 1229-34. [CrossRef]

12. Saeed I, Kapel C, Saida LA, Willingham L, Nansen P. Epidemiology of Echinococcus granulosus in Arbil province, northern Iraq, 19901998. J Helminthol 2000; 74: 83-8. [CrossRef] 